\title{
PEMBANGUNAN PERKEBUNAN BERKEADILAN DI PROVINSI RIAU
}

Oleh PAZLI (07301029)

(dibawah bimbingan Dr. Ir. Endry Martius., M.Si, Prof. Dr. Ir. Rudi Febriamansyah., M.Si, dan

Prof. Dr. Rer.Soc. Nursyirwan Effendi)

\begin{abstract}
ABSTRAK
Ada beberapa kebijakan penatagunaan lahan dan kebijakan pembangunan serta managemen perkebunan pada substansi kebijakan dan implementasinya, baik yang secara langsung di desain dari kebijakan pemerintah pusat, maupun yang digagas Pemerintah Daerah yang tidak menuju ke arah pembangunan berkeadilan di Provinsi Riau. Kondisi ini secara keseluruhan membutuhkan perhatian serius. Permasalahannya yaitu "bagaimana substansi dan implementasi kebijakan agraria aspek penatagunaan lahan dan kebijakan perkebunan aspek managemen perkebunan pada sub aspek penguasaan, pemilikan dan peruntukan lahan; sub aspek pembangunan perkebunan, infrastruktur perkebunan, pemeliharaan perkebunan, pengolahan hasil perkebunan serta kemanfaatan dan pemasaran produksi utama serta sampingan perkebunan". Apakah substansi dan implementasi kebijakan yang ada telah berkeadilan kepada perusahaan perkebunan negara, perusahaan perkebunan swasta dan rakyat?. Selanjutnya bagaimana penyempurnaannya?. Penelitian ini bertujuan untuk menggambarkan fakta-fakta berkeadilan pada substansi dan implementasi kebijakan serta bagaimana menyempurnakan ketidakadilan yang terjadi pada subjek agraria dan perkebunan. Penelitian ini dilakukan di kabupaten Kuantan Singingi, Kabupaten Kampar dan kabupaten Rokan Hulu Provinsi Riau. Metode yang digunakan adalah metode kualitatif yaitu berdasarkan konsep dan dimensi ketidakadilan antara lain; (i) marginalisasi; (ii) monopoli; (iii) dominasi, juga menggunakan analisa perbandingan antara konsep kebijakan pada substansinya dengan implementasinya berdasarkan matrik prinsip-prinsip keadilan. Data dikumpulkan dari dokumen yang relevan, wawancara dari subjek perkebunan pada 5 pola pembangunan Perkebunan.

Penelitian ini menemukan bahwa pada substansi kebijakan penatagunaan lahan (penguasaan, pemilikan dan peruntukan lahan) belum memadai untuk menampung dan mengakomodir akses, kontrol, kemanfaatan, politik kebijakan, power/kekuasaan, skala ekonomi kepada subjek agraria. Pada implementasi kebijakan penatagunaan lahan terjadi; marginalisasi kebijakan (pada akses hak, akses kesempatan, pada manfaat untuk rakyat terutama pada pola kemitraan (PIR-Trans dan PIR KKPA); monopoli dan dominasi kebijakan kepada rakyat pada sumberdaya khas dan skala ekonomi bisnis lahan. Pada substansi kebijakan pembangunan dan managemen perkebunan ditemukan ketidakadilan dalam dimensi marginalisasi, monopoli dan dominasi kepada dan sesama subjek perkebunan, yaitu tidak terdapat ketentuan yang mengatur secara kemitraan tentang managemen pengolahan hasil perkebunan, distribusi kemanfaatan dan pemasaran produksi utama dan sampingan perkebunan untǔk semua subjek perkebunan. Sedangkan pada segmen implementasi kebijakan pembangunan dan managemen perkebunan bahkan memarginalkan, memonopoli dan mendominasi rakyat petani plasma dan bukan petani plasma perkebunan. Prasyarat untuk terwujudnya kebijakan pembangunan perkebunan berkeadilan adalah integrasi kebijakan penatagunaan lahan dan kebijakan pembangunan, managemen perkebunan pada elemen substansi kebijakan dan pada elemen implementasi kebijakan yang mengakomodasi hak-hak subjek agraria dan subjek perkebunan, serta tidak bertentangan dengan prinsip-prinsip keadilan dalam kebijakan pembangunan berkeadilan dimana antara subjek agraria dan subjek perkebunan pada substansi kebijakan dan implementasi kebijakan mutlak menerapkan prinsip-prinsip tersebut.
\end{abstract}

Kata Kunci: Pembanguan perkebunan berkeadilan, kebijakan penatagunaan lahan dan perkebunan. 


\title{
EQUITABLE ESTATE DEVELOPMENT IN THE PROVINCE OF RIAU
}

\author{
By : PAZLI (07301029) \\ (Under the guidance of Dr. Ir. Endry Martius., M.Si, Prof. Dr. Ir. Rudi \\ Febriamansyah., M.Si, and Prof. Dr. Rer.Soc. Nursyirwan Effendi)
}

\begin{abstract}
There are some land use policies Tand development policies as well as the management of the estate, either directly derived from central government policy, and was initiated by the regional government not headed in the direction of "equitable development" in the province of Riau. This condition overall needs serious attention. The problem is "how the substance and implementation of a land use policy and policy in the plantation and plantation management of various aspects of the existing sub namely; sub aspects of control, ownership and land use; sub aspects of plantation development, plantation infrastructure, maintenance of plantations, plantation processing and marketing as well as the benefit of a major production and plantation side ". Is the substance and implementation of the existing policy has been fair to state plantation company, private plantation companies and the people?. Furthermore, how perfected?. This study aimed to describe the facts justice on the substance and implementation of policies and how to enhance the injustice done on the subject of agrarian and plantations. This research was conducted in the districts of Kuantan Singingi, Kampar and Rokan Hulu regency of Riau Province. The method used is a qualitative method that is based on the concept and dimensions of injustice among others; (i) marginalization; (ii) monopoly; (iii) domination, also uses a comparative analysis between the concepts of policy on substance with the implementation matrix based on the principles of justice. Data collected from the relevant documents, interviews of subjects plantations at 5 pattern plantation development. This study found that the substance of the land use policy (control, ownership and land use) is not sufficient to accommodate and accommodate the access, control, expediency, political policies, power/power, agrarian economies of scale to the subject. At a land use policy implementation occurs; marginalization policies (PIR-Trans and PIR KKPA); monopoly and domination of the policy to the people on the resources typical and scale of business economics of land. On the substance of development policy and management of plantation found injustice in the dimensions of marginalization, monopoly and domination to and fellow subjects plantation, ie there are no regulations governing in partnership on the management of plantation processing, distribution expediency and marketing of primary production and sideline plantation for all subjects plantations. While the segment of implementation of development policies and management plantations even marginalize, monopolize and dominate the people of smallholders and plantation farmers instead. A prerequisite for the realization of the development policy of plantation justice is integration policy land use and development policies, management plantation on the substantive elements of policy and on the elements of the implementation of policies that accommodate the rights of subjects of agrarian and subject plantation, and meets or does not conflict with the principles of justice in which
\end{abstract}


the equitable development policies between the subject and the subject of agrarian estates on the substance of policy and policy implementation absolute applying these principles.

Keywords: The Development of plantation justice, land use policy and plantation.

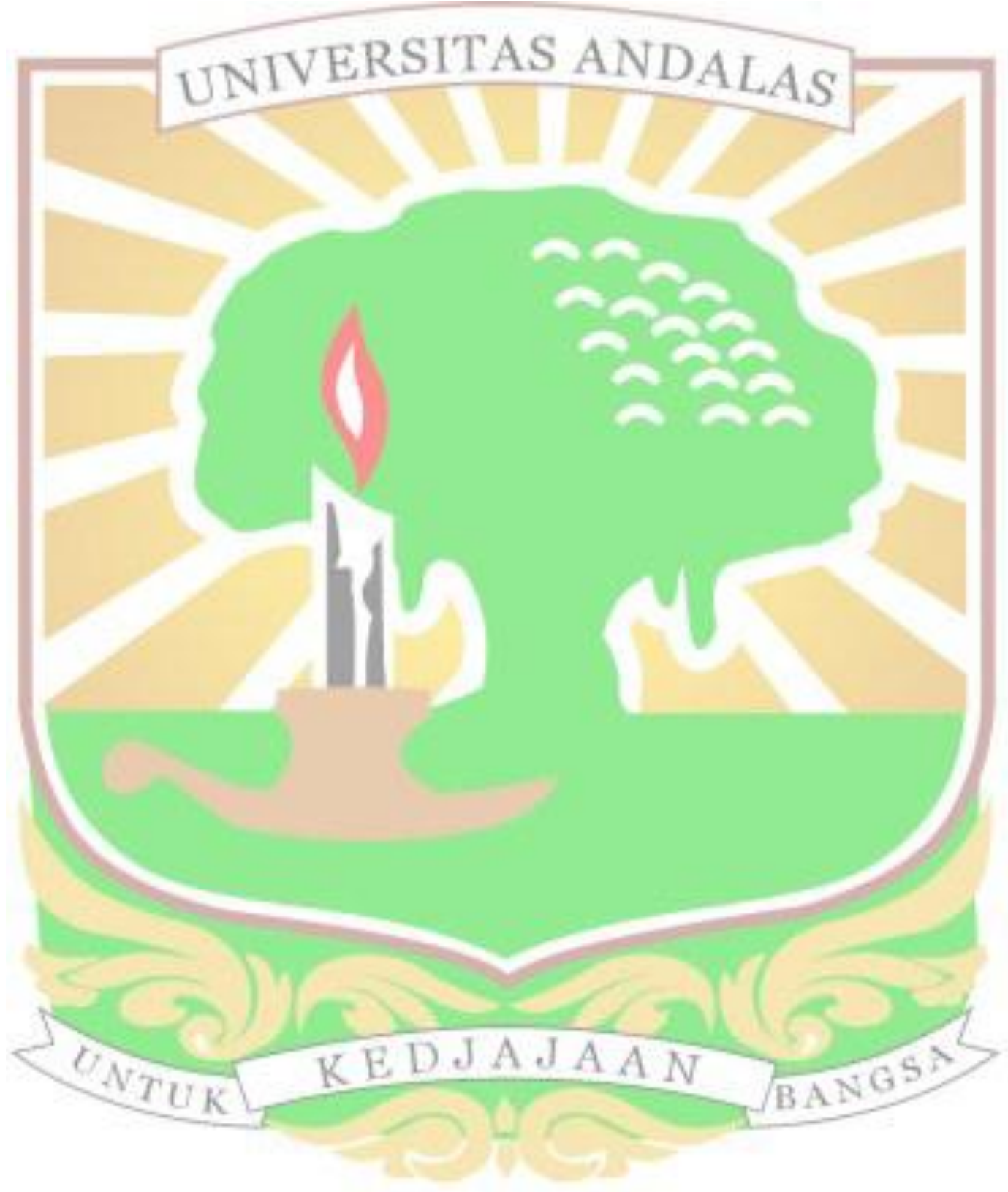

